\title{
Article \\ Sustainable Management and Policies: The Roles of Stakeholders in the Practice of Inclusive Education in Digital Transformation
}

\author{
Refia Ari ${ }^{1, *(\mathbb{C})}$, Zehra Altinay ${ }^{1}\left(\mathbb{D}\right.$, Fahriye Altinay $\left.^{1}{ }^{(}\right)$, Gokmen Dagli ${ }^{1,2}$ and Engin Ari ${ }^{3}(\mathbb{C}$ \\ 1 Institute of Graduate Studies, Societal Research and Development Center, Faculty of Education, \\ Near East University, Nicosia 99138, Turkey; zehra.altinaygazi@neu.edu.tr (Z.A.); \\ fahriye.altinay@neu.edu.tr (F.A.); gokmen.dagli@kyrenia.edu.tr (G.D.) \\ 2 Faculty of Business, Kyrenia University, Kyrenia 99320, Turkey \\ 3 Faculty of Business \& Economics, Eastern Mediterranean University, Famagusta 99628, Turkey; \\ engin.ari@emu.edu.tr \\ * Correspondence: refiaari@hotmail.com; Tel.: +90-(533)-853-2969
}

Citation: Ari, R.; Altinay, Z.; Altinay, F.; Dagli, G.; Ari, E. Sustainable Management and Policies: The Roles of Stakeholders in the Practice of Inclusive Education in Digital Transformation. Electronics 2022, 11, 585. https://doi.org/ 10.3390 /electronics 11040585

Academic Editor: Nuno Vasco Lopes

Received: 14 January 2022

Accepted: 11 February 2022

Published: 15 February 2022

Publisher's Note: MDPI stays neutral with regard to jurisdictional claims in published maps and institutional affiliations.

Copyright: (c) 2022 by the authors Licensee MDPI, Basel, Switzerland. This article is an open access article distributed under the terms and conditions of the Creative Commons Attribution (CC BY) license (https:// creativecommons.org/licenses/by/ $4.0 /)$.

\begin{abstract}
Children are a country's most valuable asset. Educating them and bringing them into society is one of the most fundamental tasks of a nation. The disadvantageous position that individuals with a disability are exposed to shows the importance of the need for inclusive education for the quality of life. It is important to use the merits of digital transformation to provide services and education for all to support sustainability. This research aims to shine a light on the problems related to inclusive education faced in the special education schools and rehabilitation centers and put forward suggestions for digital transformation. As inclusive means inclusion, social interaction, access, and equality for education, the role of digital transformation is examined for the quality of inclusive education. Self-reflection is a qualitative form which was employed in the research involving school managers and teachers who were selected randomly from the Special Education Schools and Rehabilitation Centers that participated in the research. It is revealed that most of the studies focus on inclusive education, the digital divide, social inclusion, online learning, and the implication of inclusive education in digital transformation. Although studies expose inclusive education in digital transformation, most of these have 0.20 quality criteria, showing an intensified need to extend the existing body of knowledge. It is shown that the vast majority of inclusive education aligns with the institution's inclusive education vision and purpose. Concerning financing, it is difficult to find sponsors among non-governmental organizations to support the institution's inclusive education-related material, equipment, and security needs, and Ministry of National Education funding is essential. There is a need to improve the inclusive education competencies of administrators and teachers, and in-service training should be provided. Self-improvement opportunities of administrators and teachers of the institution are significantly inadequate and should be improved.
\end{abstract}

Keywords: digital transformation; inclusive education; special education; education management; sustainable management; policy development

\section{Introduction}

The use of information and communication technologies (ICT) in the education process has escalated in recent years and has gained significance worldwide, especially after the COVID-19 pandemic. Many educational institutions and learners benefit from digital technologies such as learning management systems (LMS) and digital learning tools that allow teachers and students to enroll in online classes [1]. The introduction of digital technologies in the educational context provides the opportunity to personalize the presentation of information, select the pace of learning individually, assess competencies objectively, and 
increase the level of methodological support in the educational process [2]. Following these developments, disruptive technologies such as artificial intelligence (AI) and immersive technologies have also merged into educational programs, creating an opportunity to reach the variety of individual skills and needs of learners [3]. Especially digital transformation is highly needed for acquiring education for all.

In 2014, UNESCO defined Sustainability Education (often called Education for Sustainable Development-ESD) as: "Education for Sustainable Development allows every human being to acquire the knowledge, skills, attitudes, and values necessary to shape a sustainable future. Education for Sustainable Development means including key sustainable development issues in teaching and learning. For example, climate change, disaster risk reduction, biodiversity, poverty reduction, and sustainable consumption. It also requires participatory teaching and learning methods that motivate and empower learners to change their behavior and take action for sustainable development. Education for Sustainable Development consequently promotes competencies like critical thinking, imagining future scenarios, and collaboratively making decisions. Education for Sustainable Development requires far-reaching changes in how education is often practiced today.

Developing an individual within the changing conditions in their environment and surviving with these conditions is only possible through education. For around 4 decades, there have been intense discussions about how to best educate learners with special educational needs and disabilities, and paradigms of special education and inclusive education have been developed in digital transformation [4].

However, the disadvantageous position that individuals with a disability are exposed to shows the importance of inclusive education for the quality of life. As pointed out by [5], inclusive education is a form of general education that implies access to education for all (including people with disabilities), at the heart of which lies the elimination of any discrimination against disabled individuals.

According to [6], inclusive education is a means of transforming general education for individuals with disabilities. This transformation concentrates on developing conditions for the accessibility of education for all, including providing access to education for children with disabilities. The increase in the use of information and communications technology in education in the last 2 decades improved inclusive education for students with disabilities as distance learning created equal opportunity for everyone to access and receive a quality education. Especially after the rapid spread of the COVID-19 pandemic, the importance of information and communication technologies has been prominently raised more than ever in educational institutions. However, there are considerable challenges in using new information technologies in the educational process for students with disabilities due to the inaccessibility of digital tools and learning materials [7].

Recent studies point out the role of digital transformation by involving digital technologies in the education process and providing inclusive digital learning environments. The studies stress that providing access to inclusive education can help integrate people with different social, cultural, economic, physical, and mental differences into the active social, economic, and cultural life of society $[1,4,7]$.

Education is a mandatory process for survival. Individuals must grow up as balanced and healthy individuals to be physically and spiritually useful members of society [8].

In the last decades, a disabled individual has been acknowledged as an effective subject of society, where circumstances for their self-realization capacity and integration into society are prepared. The constitutive records that form the legal footing for education suggest that children with developmental problems have the same rights as everyone else [9].

\section{The Need for the Study}

The core themes discussed in recent studies concerning inclusive education are inclusion, holistic perspective, policy, curriculum development, learning analytics, ethical readiness, online learning, courses, training, children's rights, digital accessibility, and sustainability. In this respect, Figure 1 illustrates that inclusive education encapsulates the 
terms of disability, special education, inclusion, school reform, and learning context. It shows basic key terms studied in recent years. Recent studies underline an essential need to concentrate on social inclusion, IT risk, training of teachers, and professional readiness for practice in an inclusive educational environment. It is seen that virtual social inclusion, virtual citizenship, open education are key research areas to be examined. Additionally, implementation of policies that support schools and the use of resources for inclusive education, efficiency of inclusive education, combination of e-learning with conventional learning for ensuring socialization of persons with special needs is required. Psychological and pedagogical support of students with disabilities for the effectiveness of inclusive education and encouragement of local industries to manufacture digital devices necessary for online learning was discussed in the studies.

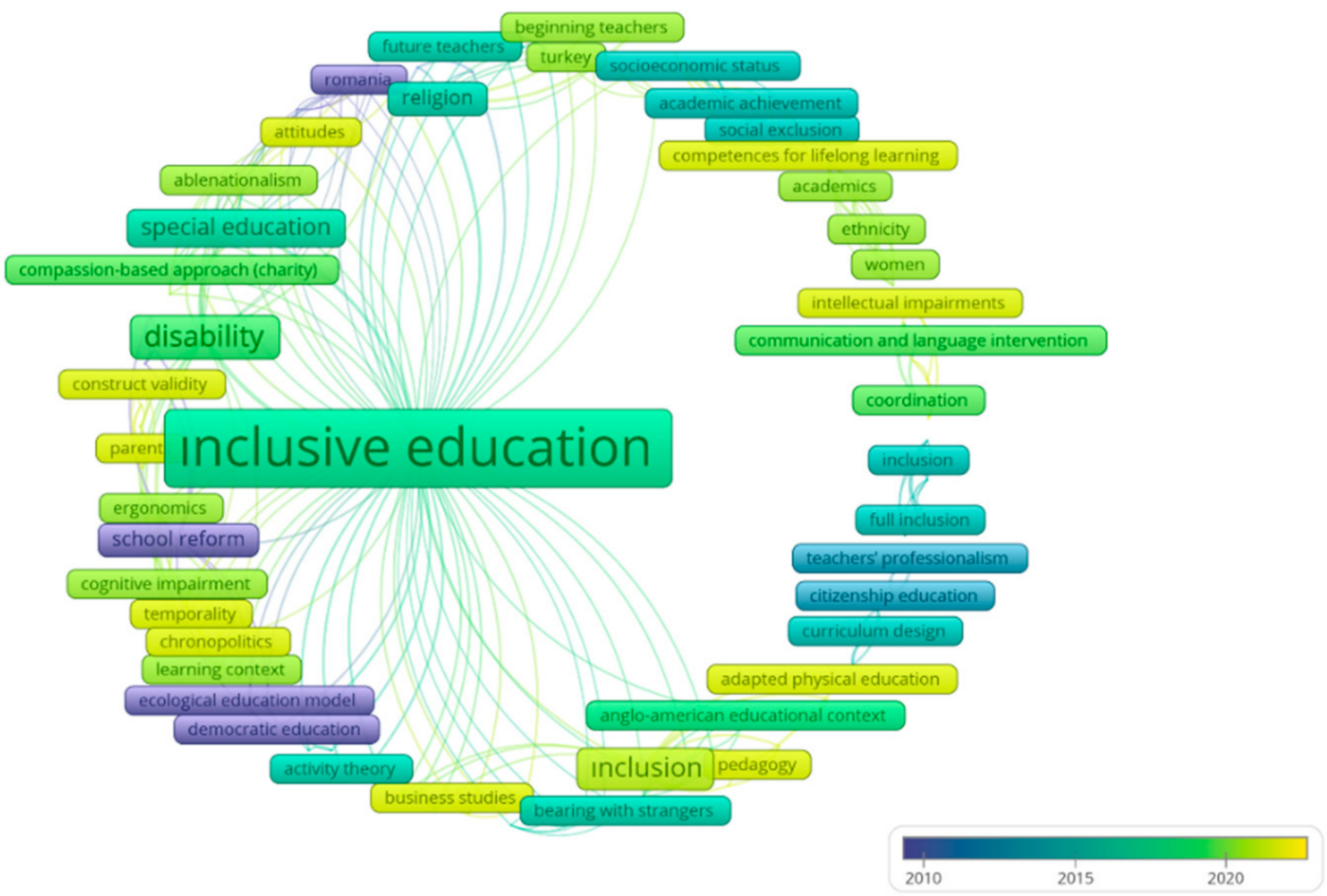

Figure 1. Key themes.

France has started a study related to inclusive education in digital transformation. Following this, Brazil started this innovative educational practice. Most of the studies are related to the European region in recent years, showing that Europe pays attention to inclusive education in digital transformation, and Arabic countries considering inclusive education is in the research. Most of the studies were conducted in 2020, giving insight into the COVID-19 period, and research related to inclusive education in digital transformation was disseminated [10].

The legal base of inclusive education is very inadequate in developing countries. According to [11], lack of standardized education causes inequality between the public and private institutions of preschool education. Ref. [11] suggests that institutions should be regulated following international standards, considering the principle of equal opportunity in education. Ref. [12] pointed out a need to redefine the term 'integration' after revising the literature and suggested that a base for special education and integration practices must be reconstructed by the Ministry of National Education.

In this respect, this research aims to shed light on the problems related to inclusive education faced in the special education schools and rehabilitation centers and put forward suggestions regarding digital transformation. As inclusive means inclusion, social interaction, access, and equality for education, the role of digital transformation is examined for the quality of inclusive education. Self-reflection as qualitative research was 
employed in the research. School managers and teachers were selected randomly from the Special Education Schools and Rehabilitation Centers involved in the research, and 5 experts participated.

The following research questions answer the aim of the research study:

RQ1. What are the $t$ quality assessments of conducted research on inclusive education in digital transformation?

RQ2. What are the roles of stakeholders in the practice of inclusive education in digital transformation?

RQ3. What are the future projections of experts in inclusive education in digital transformation?

\section{Methods}

\subsection{Research Method and Design}

A qualitative research-based reflection form was conducted to stakeholders from the field of disability and representatives of disability unions. In this respect, content analysis was done to analyze perceptions and roles for existing situations.

\subsection{Quality Assessment}

A total of 77 selected papers based on five quality criteria are used to assess the overall quality. For assessing the overall quality of each selected paper, the following five criteria were used $[13,14]$ :

QC1. Did the study report the sources and details of the outcome assessment?

QC2. Did the study compare its reported results with previous results?

QC3. Did the study conduct validity or reliability tests during the quantitative analysis?

QC4. Did the study involve a statistical analysis of significance during the quantitative assessment? For quantitative

QC5. Did the study report detailed descriptions about the involved groups (e.g., control and experimental group)? For quantitative

\subsection{Qualitative Data Collection and Analysis}

As a data collection tool in the study, self-reflection forms were prepared. The qualitative research approach usually used in-depth interviews (face-to-face interviews), direct observation, and document analysis techniques to collect data [15]. The data of this research can be obtained through the "face-to-face technique", which cannot be directly observed with other data collection tools. This provides an in-depth understanding of the participants' perspectives on the subject and is often preferred in the qualitative research approach, and is obtained through the analysis of public reports. In the face-to-face interview technique, the reasons that form the basis of the participants' answers are also the source of discovering dimensions such as emotions, thoughts, and beliefs [15]. The semistructured interview form created within the scope of this study contains four open-ended semi-structured interview questions.

To ensure the internal validity of the interview form, it has been submitted to the examination of faculty members, Faculty of Education, Department of Educational Sciences to obtain an expert opinion. In line with these views, the form was revised. After that, a working group equivalent to the working group was selected, and a pilot interview was conducted. Thus, it is ensured that the questions are clear and understandable, whether the answers given reflect the answers of the questions asked. Then, in preparing renegotiation questions, expert opinions, education management experts, and Turkish Linguists for software rules were consulted. Help was obtained for control purposes by considering whether the questions asked by examining the transcripts were clear and understandable and whether they covered the topic discussed, and the possibility of providing the necessary information. Since it was concluded that the interview questions would be provided with the desired data, the data collection process was started. In this research, content analysis was used in the analysis and interpretation of qualitative data obtained from the 
participants. Before and after the data collection, cross-examination and verification were done for data verification.

The study working group consisted of 14 participants, including six school administrators with Ph.D. degrees in management and special education and eight teachers with bachelor degrees in teacher education programs, randomly selected from the Special Education Schools and Rehabilitation Centers in North Cyprus. The Snowball sampling method was selected from purposeful sampling methods when creating the workgroup. In this sample model, this sample model was preferred because it allows the creation of a working group by interviewing the participants where the best rich data can be obtained. In the snowball sample model, after interviewing a knowledgeable participant about the research subject, it can be done with the guidance of the participant to another knowledgeable participant in that field, so rich and deep data can be obtained with this sample model.

The data obtained from the answers to the research reflection form questions were analyzed by content analysis. In content analysis, data are analyzed in four stages [16].

1. Data Encoding: In this first stage of content analysis, each participant was given a number, the data obtained from the participants were examined within the framework of the research and divided into meaningful sections, and the meaning it expressed conceptually was named and encoded. The conceptual framework of the research and the code list prepared earlier based on interview questions were finalized after examining all data. This code list served as the key list for editing data. Data outside of research questions were excluded. Then, coding keys and interview transcripts were read separately by the researchers, and necessary arrangements were made by discussing issues with "consensus" and "difference of opinion". For the reliability calculation of the study, [17] the proposed reliability formula was calculated as an average of $92 \%$. More than $70 \%$ of the reliability calculations are considered reliable for research [17].

The results obtained here are considered reliable for research. In the codings made by the researchers, the codes that match were based on achieving themes.

2. Finding themes: At this stage, the codes determined during the coding phase of the data were accepted as separate categories and evaluated as separate themes.

3. Organizing and Defining Data by Codes and Themes: At this stage, the participants' opinions are explained in a language that the reader can understand, and the opinions are presented to the reader. Footnotes were used to determine which participant the interview notes belonged to, and the interview notes were given in quotation marks.

4. Interpretation of Findings: The interpretation of the findings described and presented in detail by the researcher and the announcement of some results was made at this final stage.

\section{Results and Discussions}

\subsection{RQ1. Quality Assessment of Conducted Research on Inclusive Education in Digital Transformation}

The quality scores of 77 selected papers are based on five quality criteria as indicated above. Researchers examined selected papers regarding the availability of Quality Criteria; a value of 1 or a value of 0 was given. After that, at the end of the column, the quality score of each paper across the five QC is presented.

Examination of quality scores of selected papers (Appendix A) revealed that $48.7 \%$ (37 of 77) of the selected papers were relevant to none of the 5 quality criteria and scored zero, $47.4 \%$ (36 of 77 ) were relevant to only one of the 5 criteria, and $2.6 \%$ ( 2 of 77 ) were relevant to 2 of the 5 criteria. It is noted that less than $10 \%$ of the selected papers conducted validity and reliability tests and involved statistical significance analysis during the qualitative analysis, and gave a detailed description concerning the involved groups. It is seen that $11.8 \%$ of the selected papers report the sources and details of the outcome assessment, and $19.7 \%$ compared its reported results with previous study results.

Support provided by teachers, the role of official/formal support structures, special schools, and community collaboration are core areas to overcome challenges in the imple- 
mentation of inclusive education in digital transformation. In addition to this, designing individual inclusive learning using modern digital technologies is another challenge. While adjusting the merits of digital transformation, addressing social justice in rural areas is another challenge in inclusive education [18,19].

Furthermore, the professional knowledge of teachers needs to be enriched to reach of quality of education for sustainability [18,19]. Different countries have their inclusive practices tbe considered as an example [20-23] The study of [5] emphasizes special requirements for professional and personal training of the teacher.

According to [24-27], the outbreak of the COVID-19 pandemic has caused different types of challenges, and students experienced various challenges which paralyzed their access to online education. Accessing learning tools, use of technological tools for online learning, discrepancies in students' behavior towards online and face-to-face learning modes, and issues revolving around isolation can be listed as high considerations [28-30].

Funding to facilitate infrastructural issues of classroom buildings, seats, toilet facilities, quantity and quality of teachers, lack of cooperation among education stakeholders, inefficient electric power supply, inadequate and qualified personnel, accessibility and assessment, and abilities of parents/caregivers to support home learning are key factors to enhance inclusive education practices in digital transformation [8,31-33].

Teachers lacking confidence in establishing collaborative support networks for influencing the contexts of teacher education programs is a challenge, whereas, from the teachers' point of view, re-consideration of the ineffectiveness of the formal support structures seems essential [34].

\subsection{RQ2. Roles of Stakeholders in the Practice of Inclusive Education in Digital Transformation}

The suitability of the institution's inclusive educational purpose and its vision.

The research was created within the scope of expressing opinions about the vision and conformity of the institution's inclusive educational purpose. In this context, 14 participants were asked for their opinions. The answers to these questions were encoded, their themes were extracted, and the distributions for these themes are given in Table 1.

Table 1. The suitability of the institution's inclusive educational purpose with vision.

\begin{tabular}{lcccc}
\multicolumn{2}{c}{ Themes } & $\begin{array}{c}\text { School } \\
\text { Administrator }\end{array}$ & Teacher & Total \\
\cline { 2 - 5 } & $\mathbf{n}$ & $\mathbf{n}$ & $\mathbf{n}$ & Percentage (\%) \\
\hline $\begin{array}{c}\text { Not every activity in the institution is } \\
\text { carried out following the vision in } \\
\text { this direction }\end{array}$ & 2 & 3 & 5 & $35 \%$ \\
\hline $\begin{array}{c}\text { The mission-vision arrangement of } \\
\text { the institution } \\
\text { in the education is managed in } \\
\text { accordance with the purpose } \\
\text { and vision }\end{array}$ & 4 & 4 & 8 & $57 \%$ \\
\hline $\begin{array}{l}\text { The management of the institution is } \\
\text { sensitive to the vision in this regard }\end{array}$ & 5 & 5 & 10 & $71 \%$ \\
\hline
\end{tabular}

Regarding the size of the vision and suitability of the institution's inclusive educational purpose, the participants stated that: "Not every activity in the institution is carried out in accordance with the vision (35\%) in this direction". Again, within the scope of this dimension, they said: "the mission-vision arrangement of the Institution in education is managed following purpose and vision (57\%)". According to the participant opinions regarding the size of the vision and suitability of the institution's inclusive educational purpose, they stated: "The management of the institution is sensitive to the vision in this regard $(71 \%)^{\prime \prime}$. In this context, it is understood from the participatory opinions that the vast majority of inclusive education is in line with the vision of the institution's inclusive 
education purpose and that both school administrators and teachers have shown considerable sensitivity in this regard. In the light of these evaluations, the appropriateness of the institution's inclusive educational purpose and its participatory views are as follows:

$\mathrm{M}(4)$ "I think that the institution is managed per the purpose of mission-vision regulation on education."

$\mathrm{M}(2)$ "The institution I work for is not, in my opinion, a school suitable for inclusive education".

$\mathrm{T}(5)$ "Yes, every activity in the institution is carried out in this direction".

Providing material, equipment, and equipment security needs within the scope of inclusive education and solutions:

The research was created within the scope of providing material, equipment, and equipment security needs within the scope of inclusive education of the institution, and to express opinions about solutions. In this context, 14 participants were asked for their opinions. The answers to these questions were encoded, the themes were extracted, and the distributions for these themes were given in Table 2.

Table 2. Providing material, equipment, and equipment security needs and solutions within the scope of inclusive education of the institution.

\begin{tabular}{|c|c|c|c|c|}
\hline \multirow[t]{2}{*}{ Themes } & $\begin{array}{c}\text { School } \\
\text { Administrator }\end{array}$ & Teacher & & Total \\
\hline & $\mathbf{n}$ & $\mathbf{n}$ & $\mathbf{N}$ & Percentage $\%$ \\
\hline $\begin{array}{l}\text { Lack of budget in meeting material and } \\
\text { equipment needs in the institution }\end{array}$ & 4 & 5 & 9 & $64 \%$ \\
\hline $\begin{array}{l}\text { Meeting the material and equipment } \\
\text { needs of the institution with } \\
\text { non-governmental organizations and } \\
\text { the Ministry of National Education }\end{array}$ & 6 & 7 & 13 & $92 \%$ \\
\hline Difficulties in sponsoring institutions & 3 & 3 & 6 & $42 \%$ \\
\hline
\end{tabular}

According to the participant opinions regarding the provision of material, equipment, and equipment security needs within the scope of inclusive education and the size of solution proposals, they stated that there is a "lack of budget $(64 \%)$ in meeting the needs of materials and equipment in the institution". Again, within the scope of this dimension, they said that "The material and equipment need of the Institution are met by non-governmental organizations and the Ministry of National Education (92\%)."

They stated that there are "difficulties in sponsoring institutions (42\%) according to the participatory opinions regarding the provision of material, equipment and equipment security needs within the scope of inclusive education and the size of solutions. In this context, it is understood from the participatory opinions that the vast majority of the institution's material, equipment, and security needs within the scope of inclusive education and the scope of solution proposals are budgetary shortages, and there are difficulties in finding significant sponsors of both school administrators and teachers in this regard. In addition, it can be said according to the participatory opinions that the material and equipment needs of the institution should be met by non-governmental organizations and the Ministry of National Education. In the light of these evaluations, the organization's material, equipment, and equipment security needs within the scope of inclusive education and the size of solution proposals and participant opinions are presented below;

$\mathrm{T}$ (1) "There are problems. The sponsorship budget is inadequate".

M (2) "Our school budget is in bad shape. We can't even buy toner for the teachers.

The ministry doesn't pay for a few more materials like Toner".

$\mathrm{T}$ (8) "These needs are not met by NGOs and the Ministry of National Education". 
Training for increasing the equipment for school administrators and teachers within the scope of inclusive education of the institution:

The research was created as part of the discussion concerning providing education to increase the equipment of school administrators and teachers within the scope of inclusive education. In this context, 14 participants were asked for their opinions. The answers to these questions were encoded, their themes were extracted, and the distributions for these themes were given in Table 3.

Table 3. Providing training to increase the equipment of school administrators and teachers within the scope of inclusive education of the institution.

\begin{tabular}{|c|c|c|c|c|}
\hline \multirow{2}{*}{ Themes } & $\begin{array}{c}\text { School } \\
\text { Administrator }\end{array}$ & Teacher & & Total \\
\hline & $\mathbf{n}$ & $\mathbf{n}$ & $\mathrm{n}$ & Percentage (\%) \\
\hline $\begin{array}{c}\text { Training for school administrators and } \\
\text { teachers to increase their equipment } \\
\text { within the scope of inclusive education } \\
\text { of the institution }\end{array}$ & 6 & 6 & 12 & $85 \%$ \\
\hline $\begin{array}{l}\text { Lack of hardware within the scope of } \\
\text { inclusive education of the institution }\end{array}$ & 4 & 4 & 8 & $57 \%$ \\
\hline
\end{tabular}

Regarding the size of the institution's training to increase the equipment of school administrators and teachers within the scope of inclusive education, the participant stated that "Education for school administrators and teachers $(85 \%)$ is to increase the equipment within the scope of inclusive education of the institution". Again, within the scope of this dimension, they said that "there is a lack of equipment within the scope of inclusive education of the institution (57\%)". In this context, it is understood that education should be provided to increase the equipment of school administrators and teachers within the scope of inclusive education of the institution. In this context, it can be proposed that in-service training should be planned and implemented in order to eliminate the lack of inclusive training equipment of the institution. In light of these assessments, the extent of providing training for increasing the equipment of school administrators and teachers within the scope of inclusive education and participatory opinions are as shown below:

$\mathrm{T}$ (3) "Informative training is important for school administrators and teachers to understand exactly what is happening, their benefits and effects of inclusive education, and to increase their equipment".

M (6) "Training is required to develop for adequate equipment".

$\mathrm{T}$ (7) "Not enough. The equipment of educators in special educational institutions should be increased".

The situation and solutions of the institution's research and development opportunities for school administrators and teachers in the issue of inclusive education.

The research was created as part of the institution's ability to present views on the situation and solutions of the research and development opportunities of school administrators and teachers in the issue of inclusive education. In this context, 14 participants were asked for their opinions. The answers to these questions were encoded, their themes were extracted, and the distributions for these themes are given in Table 4.

The participants stated that the institution's research and development opportunities for school administrators and teachers concerning the subject of inclusive education are "inadequate (85\%) within the scope of inclusive education in the institution". Again, within the scope of this dimension, they said that "Educators in the institution can improve themselves and do not have educational needs (21\%)". They stated that "In-service trainings $(92 \%)$ within the scope of educators' opportunities to develop themselves" were according to the participatory opinions regarding the extent of the research and development opportunities of school administrators and teachers in the subject of inclusive education. In this 
context, it is understood from the participatory opinions that the majority of the research and development opportunities of school administrators and teachers in the scope of selfimprovement in inclusive education are significantly inadequate in their opportunities for self-improvement according to the size of the situation and solution proposals. In addition, it can be said, according to the participatory opinions, that both school administrators and teachers need serious training within the scope of self-development opportunities. In light of these assessments, the extent of the research and development opportunities of school administrators and teachers on self-improvement in inclusive education and the dimension of solution proposals and participatory opinions are presented below;

$\mathrm{M}(3)$ “Unfortunately, I don't think it's enough. I think the teacher can update the education policy in this sense".

$\mathrm{T}(5)$ "Interest, desire, and work to create can be encouraged".

M (4) "In-service training can be arranged".

Table 4. The situation and solution of the institution's research and development opportunities for school administrators and teachers in the issue of inclusive education.

\begin{tabular}{ccccc}
\hline \multirow{2}{*}{ Themes } & $\begin{array}{c}\text { School } \\
\text { Administrator }\end{array}$ & $\begin{array}{c}\text { Total } \\
\text { Teacher }\end{array}$ & Total \\
\cline { 2 - 5 } & $\mathbf{n}: 6$ & $\mathbf{n}: 8$ & $\mathbf{n}$ & Percentage (\%) \\
\hline $\begin{array}{c}\text { Lack of opportunities to improve } \\
\text { yourself within the scope of inclusive } \\
\text { education in the institution }\end{array}$ & 5 & 7 & 12 & $85 \%$ \\
\hline $\begin{array}{c}\text { Educators in the institution are } \\
\text { sufficient to improve themselves and } \\
\text { do not have educational needs }\end{array}$ & 1 & 2 & 3 & $21 \%$ \\
\hline $\begin{array}{c}\text { In-service trainings within the scope of } \\
\text { the opportunities of self-improvement } \\
\text { of educators }\end{array}$ & 6 & 7 & 13 & $92 \%$ \\
\hline
\end{tabular}

3.3. RQ3. Future Projections of Experts in the Practice of Inclusive Education in Digital Transformation

\subsubsection{Current Situation of Inclusive Education in Digital Transformation}

Experts (N:5) stated that the digital transformation process, information technologies, and services are vital and gained importance in inclusive education. Regarding experts' views, there are different applications according to the facilities and also about technological knowledge of the teachers. However, experts stated that currently, it is not possible to say that all of these applications are common or accessible to everyone.

Experts (N:3) underlined that ICT help to overcome limitations from cognitive, sensory, and physical disabilities. ICT enhances communication between students with special needs with other students and teachers. ICT allows students to acquire skills faster. ICT allows a better diagnosis of student needs. ICT provides multisensorial communication. ICT facilitates social and professional insertion. ICT provides social meetings. ICT lessens the sense of academic and personal failure.

\subsubsection{The Challenges of Inclusive Education in Digital Transformation}

Regarding challenges when using ICT for students with special needs, there is the high economic cost, which makes it impossible to provide to all students who need them, and the rapid advance of technology, often outdating devices in a short period of time, are considered challenges by experts (N:4). Experts also cited a professionals' lack of knowledge and preparation, and the inappropriate use of ICT which can lead to student passivity, lack of imagination, intolerance, and individualism. Most of the experts underlined that inaccessibility of opportunities equally by everyone, schools, teachers, and students in the education system do not have enough technology. Also, there is not enough or enough 
variety of technology and software available, the existant mainly aimed at certain disability groups. Teachers, students, and families in the education system do not have sufficient information technology literacy (N:4).

\subsubsection{Future Projections of Inclusive Education in Digital Transformation}

Experts (N:5) pointed out that technology and software in this field should be supported for the future. Accessibility criteria should be followed in information technologies used in the education system, and these services should be expanded. Technology literacy trainings should be organized for families and students, especially for teachers. ICT enhances students' autonomy, as these tools can be adapted to any need and can be personalized.

\section{Discussion}

The importance of digital transformation for providing access to inclusive education learners is pointed out. The studies stress that providing access to inclusive education can help integrate people with different social, cultural, economic, physical, and mental differences into the active social, economic, and cultural life of society. However, our qualitative research findings showed the need to improve the inclusive education competencies of administrators and teachers and the need for providing self-improvement opportunities for them are the main challenges at the Special Education Schools and Rehabilitation Centers in attaining a digitally transformed inclusive education. In light of the findings obtained as a result of personal opinion forms in the qualitative research pattern, they stated that according to the participant opinions regarding the size of the vision and conformity of the institution's inclusive educational purpose, "Not every activity in the institution is carried out in accordance with the vision (35\%)". Again, within the scope of this dimension, they said that "the mission-vision arrangement of the Institution in education is managed per the purpose and vision (57\%)". According to the participant opinions regarding the size of the vision and suitability of the institution's inclusive educational purpose, they stated that: "The management of the institution is sensitive to the vision in this regard (71\%)." In this context, it is understood from the participatory opinions that the vast majority of inclusive education is in line with the vision of the institution's inclusive education purpose and that both school administrators and teachers have shown considerable sensitivity in this regard. According to the participant opinions regarding the provision of material, equipment, and equipment security needs within the scope of inclusive education and the size of solution proposals, they stated that there is a "lack of budget (64\%) in meeting the needs of materials and equipment in the institution". Again, within the scope of this dimension, they said that: "The material and equipment need of the Institution are met by non-governmental organizations and the Ministry of National Education (92\%)". They stated that there are "difficulties in sponsoring institutions (42\%) according to the participatory opinions regarding the provision of material, equipment, and equipment security needs within the scope of inclusive education and the size of solutions. In this context, it was understood from the participatory opinions that the vast majority of the institution's material and equipment security needs within the scope of inclusive education and the scope of solution proposals are budgetary shortages, and there are difficulties in finding significant sponsors of both school administrators and teachers in this regard. In addition, it can be said according to the participatory opinions that the material and equipment needs of the institution should be met by non-governmental organizations and the Ministry of National Education.

To reach out sustainable managerial implications in inclusive education, Table 5 below summarizes actions for future projections. 
Table 5. Sustainable managerial implications in inclusive education.

\begin{tabular}{ll}
\hline Potential Considerations & Action and Policy \\
\hline $\begin{array}{l}\text { The vast majority of inclusive education is in line with the } \\
\text { vision of the institution's inclusive education purpose, and both } \\
\text { school administrators and teachers have shown considerable } \\
\text { sensitivity in this regard. }\end{array}$ & $\begin{array}{l}\text { human resources and } \\
\text { management }\end{array}$ \\
\hline $\begin{array}{l}\text { The vast majority of the institution's material and equipment } \\
\text { security needs within the scope of inclusive education and the } \\
\text { scope of solution proposals are budgetary shortages, and there } \\
\text { are difficulties in finding significant sponsors of both school } \\
\text { administrators and teachers in this regard. }\end{array}$ & $\begin{array}{l}\text { capacity building for } \\
\text { infrastructure and financing }\end{array}$ \\
\hline $\begin{array}{l}\text { Education should be provided to increase the equipment of } \\
\text { school administrators and teachers within the scope of inclusive } \\
\text { education of the institution. }\end{array}$ & professional development \\
\hline $\begin{array}{l}\text { The majority of the research and development opportunities of } \\
\text { school administrators and teachers in the scope of } \\
\text { self-improvement in inclusive education are }\end{array}$ & research and development \\
significantly inadequate. & \\
\hline
\end{tabular}

\section{Conclusions}

Regarding the scope of the institution's training to increase the equipment of school administrators and teachers within the realm of inclusive education, the participant stated that: "Education for school administrators and teachers (85\%) is to increase the equipment within the scope of inclusive education of the institution". Again, regarding this dimension, they said that: "there is a lack of equipment regarding inclusive education at the institution $(57 \%)^{\prime \prime}$. In this context, it is understood that education should be provided to increase the equipment for school administrators and teachers within the scope of inclusive education of the institution. In this context, it can be proposed that in-service training should be planned and implemented in order to eliminate the lack of inclusive training equipment of the institution. They stated that the institution's research and development opportunities for school administrators and teachers on the subject of inclusive education are "inadequate $(85 \%)$ within the scope of inclusive education in the institution". Again, within the scope of this dimension, they said that: "Educators in the institution are sufficient to improve themselves and do not have educational needs (21\%)". Regarding the status of the research and development opportunities of school administrators and teachers in the subject of inclusive education, and the size of solution proposals, the participants stated that: "Inservice pieces of training (92\%) within the scope of the opportunities of self-improvement of educators" were made. In this context, it is understood from the participatory opinions that the majority of the research and development opportunities of school administrators and teachers in the scope of self-improvement in inclusive education are significantly inadequate regarding their opportunities for self-improvement according to the nature of the situation and solution proposals. In addition, within the scope of this dimension, it can be proposed that both school administrators and teachers need serious training within the scope of self-improvement opportunities and that the opportunities to improve themselves through in-service training can be proposed.

\section{Future Recommendations and Limitations}

Research is limited to qualitative research employed in one case from one region of the Mediterranean. As a further recommendation, experiential research that goes beyond the limitations of this study can be conducted to evaluate the effectiveness of bringing theory into practice. In addition, in-service trainings could inform the capacity for building sustainable, practical solutions for coordination and collaboration on managerial aspects of those centers for the future. 


\section{Patents}

This section is not mandatory but may be added if patents result from the work reported in this manuscript.

Author Contributions: Conceptualization, R.A., F.A., G.D., Z.A.; methodology, F.A., G.D.; software, G.D., E.A.; validation, F.A., Z.A., G.D.; formal analysis, G.D., E.A.; investigation, G.D.; resources, G.D., F.A.; data curation, G.D., E.A.; writing-original draft preparation, G.D.; writing-review and editing, Z.A., E.A., F.A., G.D.; visualization, G.D.; supervision, Z.A., F.A., G.D.; project administration, G.D. All authors have read and agreed to the published version of the manuscript.

Funding: This research received no external funding.

Institutional Review Board Statement: This study was conducted in accordance with the University Ethical Board Approvement.

Informed Consent Statement: Informed consent was obtained from all subjects involved in the study.

Data Availability Statement: Data were selected from official platforms listed in Section 2.2 of this article.

Conflicts of Interest: The authors declare no conflict of interest.

Appendix A. The Quality Scores of the Selected Papers

\begin{tabular}{|c|c|c|c|c|c|c|}
\hline Studies & QC1 & QC2 & QC3 & QC4 & QC5 & Quality Score \\
\hline [1] & 0 & 0 & 0 & 0 & 1 & 0.20 \\
\hline [2] & 1 & 0 & 0 & 0 & 0 & 0.20 \\
\hline [4] & 1 & 0 & 0 & 0 & 0 & 0.20 \\
\hline [5] & 0 & 0 & 0 & 0 & 0 & 0 \\
\hline [6] & 0 & 0 & 0 & 0 & 1 & 0.20 \\
\hline [7] & 0 & 0 & 0 & 0 & 1 & 0.20 \\
\hline [8] & 0 & 0 & 0 & 0 & 1 & 0.20 \\
\hline [9] & 0 & 1 & 0 & 0 & 0 & 0.20 \\
\hline [10] & 0 & 0 & 1 & 0 & 0 & 0.20 \\
\hline [14] & 0 & 0 & 0 & 0 & 0 & 0 \\
\hline [35] & 0 & 0 & 1 & 0 & 0 & 0.20 \\
\hline [36] & 0 & 1 & 0 & 0 & 0 & 0.20 \\
\hline [18] & 0 & 1 & 0 & 0 & 0 & 0.20 \\
\hline [20] & 1 & 0 & 0 & 0 & 0 & 0.20 \\
\hline [21] & 0 & 0 & 0 & 0 & 1 & 0.20 \\
\hline [19] & 0 & 0 & 0 & 0 & 1 & 0.20 \\
\hline [22] & 0 & 0 & 0 & 0 & 0 & 0 \\
\hline [23] & 0 & 0 & 0 & 0 & 0 & 0 \\
\hline [24] & 0 & 0 & 0 & 0 & 0 & 0 \\
\hline [25] & 0 & 1 & 0 & 0 & 0 & 0.20 \\
\hline [26] & 0 & 0 & 0 & 0 & 1 & 0.20 \\
\hline [27] & 0 & 1 & 0 & 0 & 0 & 0.20 \\
\hline [28] & 1 & 0 & 0 & 0 & 0 & 0.20 \\
\hline [29] & 1 & 0 & 0 & 0 & 0 & 0.20 \\
\hline [30] & 1 & 0 & 0 & 0 & 0 & 0.20 \\
\hline [31] & 0 & 1 & 0 & 0 & 0 & 0.20 \\
\hline [32] & 0 & 1 & 0 & 0 & 0 & 0.20 \\
\hline [33] & 0 & 1 & 0 & 0 & 0 & 0.20 \\
\hline [34] & 0 & 0 & 0 & 0 & 0 & 0 \\
\hline [37] & 0 & 0 & 0 & 0 & 0 & 0 \\
\hline [38] & 0 & 0 & 0 & 0 & 0 & 0 \\
\hline [39] & 0 & 0 & 0 & 1 & 0 & 0.20 \\
\hline [40] & 1 & 0 & 0 & 0 & 0 & 0.20 \\
\hline
\end{tabular}




\begin{tabular}{|c|c|c|c|c|c|c|}
\hline Studies & QC1 & QC2 & QC3 & QC4 & QC5 & Quality Score \\
\hline [41] & 1 & 0 & 0 & 0 & 0 & 0.20 \\
\hline [42] & 0 & 0 & 1 & 0 & 0 & 0.20 \\
\hline [43] & 0 & 0 & 0 & 0 & 0 & 0 \\
\hline [44] & 0 & 0 & 0 & 0 & 0 & 0 \\
\hline [45] & 0 & 1 & 0 & 0 & 0 & 0.20 \\
\hline [46] & 0 & 0 & 0 & 0 & 0 & 0 \\
\hline [47] & 0 & 0 & 0 & 0 & 0 & 0 \\
\hline [48] & 0 & 1 & 0 & 0 & 0 & 0.20 \\
\hline [49] & 0 & 0 & 0 & 0 & 0 & 0 \\
\hline [50] & 0 & 0 & 0 & 0 & 0 & 0 \\
\hline [51] & 0 & 1 & 0 & 0 & 0 & 0.20 \\
\hline [52] & 0 & 0 & 0 & 0 & 0 & 0 \\
\hline [53] & 0 & 0 & 0 & 0 & 0 & 0 \\
\hline [54] & 0 & 0 & 1 & 1 & 0 & 0.40 \\
\hline [55] & 0 & 0 & 0 & 0 & 0 & 0 \\
\hline [56] & 0 & 0 & 0 & 0 & 0 & 0 \\
\hline [57] & 0 & 0 & 1 & 0 & 0 & 0.20 \\
\hline [58] & 0 & 0 & 0 & 0 & 0 & 0 \\
\hline [59] & 0 & 0 & 0 & 0 & 0 & 0 \\
\hline [60] & 0 & 0 & 0 & 0 & 0 & 0 \\
\hline [61] & 0 & 0 & 0 & 0 & 0 & 0 \\
\hline [62] & 0 & 0 & 0 & 0 & 0 & 0 \\
\hline [63] & 0 & 0 & 0 & 0 & 0 & 0 \\
\hline [64] & 0 & 0 & 0 & 0 & 0 & 0 \\
\hline [65] & 0 & 0 & 0 & 0 & 0 & 0 \\
\hline [66] & 0 & 0 & 0 & 0 & 0 & 0 \\
\hline [67] & 0 & 1 & 0 & 0 & 0 & 0.20 \\
\hline [68] & 0 & 1 & 1 & 0 & 0 & 0.40 \\
\hline [69] & 0 & 0 & 0 & 0 & 0 & 0 \\
\hline [70] & 0 & 0 & 0 & 0 & 0 & 0 \\
\hline [71] & 0 & 0 & 0 & 0 & 0 & 0 \\
\hline [72] & 0 & 0 & 1 & 0 & 0 & 0.20 \\
\hline [73] & 0 & 0 & 1 & 1 & 0 & 0.40 \\
\hline [74] & 0 & 0 & 0 & 0 & 0 & 0 \\
\hline [75] & 0 & 1 & 0 & 0 & 0 & 0.20 \\
\hline [76] & 0 & 0 & 0 & 0 & 0 & 0 \\
\hline [77] & 0 & 0 & 0 & 0 & 0 & 0 \\
\hline
\end{tabular}

\section{References}

1. Bong, W.K.; Chen, W. Increasing faculty's competence in digital accessibility for inclusive education: A systematic literature review. Int. J. Incl. Educ. 2021, 1-17. [CrossRef]

2. Mihovska, A.; Prevedourou, D.; Tsankova, J.; Manolova, A.; Poulkov, V. Building Adaptive And Inclusive Education Readiness Through Digital Technologies. In Proceedings of the 2021 Joint International Conference on Digital Arts, Media and Technology with ECTI Northern Section Conference on Electrical, Electronics, Computer and Telecommunication Engineering, Cha-am, Thailand, 3-6 March 2021; pp. 384-388.

3. Abad-Segura, E.; González-Zamar, M.D.; Infante-Moro, J.C.; Ruipérez García, G. Sustainable management of digital transformation in higher education: Global research trends. Sustainability 2020, 12, 2107. [CrossRef]

4. Hornby, G.; Kauffman, J.M. Special and Inclusive Education: Perspectives, Challenges and Prospects. Educ. Sci. 2021, 11, 362. [CrossRef]

5. Chelnokova, E.A.; Kaznacheeva, S.N.; Egorov, E.E.; Shobonova, L.Y.; Lebedeva, T.E. Human resources support for inclusive education. Education 2019, 1, 2.

6. Mikhailenko, O.; Bashiyeva, Z.; Balkizova, F.; Nagoev, B. The implementation of inclusive education in the Kabardino-Balkarian Republic under the conditions of digitalization. E3S Web Conf. 2021, 273, 12115. [CrossRef]

7. Mhlanga, D.; Moloi, T. COVID-19 and the digital transformation of education: What are we learning on 4IR in South Africa? Educ. Sci. 2020, 10, 180. [CrossRef]

8. Aimua, E.P.; Paul, J. Covid-19 and the Educational Sector: Challenges and the Need for Inclusive Education in Nigeria. Asian J. Econ. Bus. Account. 2021, 21, 15-23. [CrossRef] 
9. Peters, M.A.; Besley, T.A. Social Exclusion/Inclusion: Foucault's analytics of exclusion, the political ecology of social inclusion and the legitimation of inclusive education. Open Rev. Educ. Res. 2014, 1, 99-115. [CrossRef]

10. Yaskevich, D. Digital Technologies, as a Factor in the Search for a New Quality of Inclusive Education. E3S Web Conf. 2021, 258, 07086. [CrossRef]

11. Dağbaşı, S. Kuzey Kıbrıs Türk Cumhuriyeti'nde Okul Öncesi Eğitim Kurumlarının Öğrenme Ortamlarının Uluslararası Standartlar Açısından İncelenmesi. Master's Thesis, Doğu Akdeniz Üniversitesi, Mağusa, Turkey, 2018.

12. Alemdaroğlu, Y. Özel Ĕ̆itim Öğretmelerinin ve Sımı Öğretmenlerinin Bütünleştirme Uygulamalarına Yönelik Görüşleri (KKTC Örneği); Yayınlanmamış Yüksek Lisans Tezi, Özel Eğitim Ana Bilim Dalı, Eğitim Bilimleri Estitüsü; Yakındoğu Üniversitesi: KKTC, Turkey, 2019.

13. Webster, J.; Watson, R.T. Analyzing the Past to Prepare for the Future: Writing a Literature Review. MIS Q. 2002, 26, xiii-xxiii.

14. Moher, D.; Liberati, A.; Tetzlaff, J.; Altman, D.G. Preferred Reporting Items for Systematic Reviews and Meta-Analyses: The PRISMA Statement. Int. J. Surg. 2010, 8, 336-341. [CrossRef]

15. Legard, R.; Keegan, J.; Ward, K. In-depth Interviews. In Qualitative Research Practice; Richie, J., Lewis, J., Eds.; Sage: London, UK, 2003; pp. 139-168.

16. Yıldırım, A.; Şimşek, H. Sosyal Bilimlerde Nitel Araştırma Yöntemleri; Seçkin Yayıncılık: Ankara, Turkey, 2011.

17. Miles, M.B.; Huberman, A.M. Qualitative Data Analysis: An Expanded Source Book, 2nd ed.; Sage: Thousand Oaks, CA, USA, 1994.

18. Wahyudi, A.; Yani, M.T.; Df, A.S.M. The Urgency of Inclusive Education in Realizing Sustainable Development. 2019. Available online: http:/ / eprints.eudl.eu/id/eprint/7591/ (accessed on 10 February 2022).

19. Yilmaz, R.K.; Yeganeh, E. Who and How Do I Include? A Case Study on Teachers' Inclusive Education Practices. Int. J. Progress. Educ. 2021, 17, 406-429. [CrossRef]

20. Valencia-Forrester, F.; Patrick, C.J.; Webb, F.; Backhaus, B. Practical Aspects of Service Learning Make Work-Integrated Learning Wise Practice for Inclusive Education in Australia. Int. J. Work.-Integr. Learn. 2019, 20, 31-42.

21. Asiri, A.A. Teachers' Concern and Professional Development Needs in Adopting Inclusive Education in Saudi Arabia, Based on Their Gender for Vision 2030. J. Educ. Learn. 2020, 9, 9-20. [CrossRef]

22. Qodirova, F.U. Methodical cluster- an innovative mechanism to increase the efficiency of general secondary and inclusive education. Eur. J. Res. Reflect. Educ. Sci. 2020, 8, 115-122.

23. Giulia, M.U.R.A.; Alcaraz, A.O.; Aleotti, F.; Combo, M.O.; Gomez, M.R.; Diamantini, D. Inclusive Education in Spain and Italy: Evolution and Current Debate. J. Incl. Educ. Res. Pract. 2020, 1, 1-23.

24. Uleanya, C.; Ezeji, I.N.; Uleanya, M.O. Inclusive Education in the Face of a Global Pandemic: Providing Support. Multicult. Educ. 2021, 7. [CrossRef]

25. Anderson, J.; Boyle, C. Looking in the mirror: Reflecting on 25 years of inclusive education in Australia. Int. J. Incl. Educ. 2019, 23, 796-810. [CrossRef]

26. Pankratova, O.P.; Konopko, E.A. Remote Training of Teachers for IT Navigation in Inclusive Education; Yalta, Crimea, 2019; pp. 493-498. Available online: http:/ / ceur-ws.org/Vol-2834/Paper44.pdf (accessed on 10 February 2022).

27. Araujo, P.S.; Gouveia, L.B. Governance Using an Information Management Platform to Support an Inclusive Education ContextCraei. 2017. Available online: https:/ / doi.org/10.5748/9788599693131-14CONTECSI/DOC-5099 (accessed on 10 February 2022).

28. Belousova, A.; Mochalova, Y.; Tushnova, Y. Attitude to Distance Learning of Schoolchildren and Students: Subjective Assessments of Advantages and Disadvantages. Educ. Sci. 2022, 12, 46. [CrossRef]

29. Sáiz-Manzanares, M.C.; Gutiérrez-González, S.; Rodríguez, Á.; Alameda Cuenca-Romero, L.; Calderón, V.; Queiruga-Dios, M.Á Systematic Review on Inclusive Education, Sustainability in Engineering: An Analysis with Mixed Methods and Data Mining Techniques. Sustainability 2020, 12, 6861. [CrossRef]

30. García-Peñalvo, F.J. Avoiding the dark side of digital transformation in teaching. An institutional reference framework for eLearning in higher education. Sustainability 2021, 13, 2023. [CrossRef]

31. Teschers, C. Proposing a Holistic Inclusive Education Model for Policy, Curriculum and Classroom Development. N. Zealand J. Teach. Work. 2020, 17, 73-87. [CrossRef]

32. Stripe, K.; Dallison, K.; Alexandrou, D. Using Personas to Promote Inclusive Education in an Online Course. Int. J. Technol. Incl. Educ. IJTIE 2021, 10. [CrossRef]

33. Ydo, Y. Inclusive education: Global priority, collective responsibility. Prospects 2020, 49, 97-101. [CrossRef] [PubMed]

34. Nel, N.M.; Tlale, L.D.N.; Engelbrecht, P.; Nel, M. “Teachers' perceptions of education support structures in the implementation of inclusive education in South Africa". KOERS-Bull. Christ. Scholarsh. 2016, 81, 1-14. [CrossRef]

35. Dube, B. Rural Online Learning in the Context of COVID-19 in South Africa: Evoking an Inclusive Education Approach. Multidiscip. J. Educ. Res. 2020, 10, 135-157. [CrossRef]

36. Read, T. Towards a new model for inclusive education based on virtual social inclusion and mobile openness. World J. Educ. Technol. Curr. Issues. 2020, 12, 14-22. [CrossRef]

37. Kurian, S.; Ramanathan, H.N.; de Alwis, C. E-learning in India and Sri Lanka: A Cross-Cultural Study. Asia Pac. J. Inf. Systems. 2021, 31, 102-120. [CrossRef]

38. McNamara, S.W.T.; Haegele, J.A. Undergraduate students' experiences with educational podcasts to learn about inclusive and integrated physical education. Eur. Phys. Educ. Review. 2021, 27, 185-202. [CrossRef] 
39. McKown, G.; Hirsch, S.E.; Carlson, A.; Allen, A.A.; Walters, S. Preservice special education teachers' perceptions of mixed-reality simulation experiences. Teach. Educ. Spec. Educ. 2021, 10. [CrossRef]

40. Hannon, L.; O’Donnell, G.M. Teachers, parents, and family-school partnerships: Emotions, experiences, and advocacy. J. Educ. Teach. 2021. [CrossRef]

41. Dickinson, H.; Smith, C.; Yates, S.; Tani, M. The importance of social supports in education: Survey findings from students with disability and their families during COVID-19. Disabil. Soc. 2021. [CrossRef]

42. Alyamani, K.A.Z.; Aleid, M.A. Impact of distance education to reduce the effects of the (COVID 19) on the educational attainment level of students of King Faisal University. Rev. Int. Geogr. Educ. Online 2021, 11. [CrossRef]

43. Reinhardt, K.S.; Robertson, P.M.; Johnson, R.D. Connecting inquiry and Universal Design for Learning (UDL) to teacher candidates' emerging practice: Development of a signature pedagogy. Educ. Action Res. 2021, 23, 1-18. [CrossRef]

44. Fahm, A.O.; Azeez, A.L.; Imam-Fulani, Y.O.; Mejabi, O.V.; Faruk, N.; Abdulrahaman, M.D.; Olawoyin, L.A.; Oloyede, A.A.; Surajudeen-Bakinde, N.T. ICT enabled Almajiri education in Nigeria: Challenges and prospects. Educ. Inf. Technol. 2021, 1-35. [CrossRef]

45. Batdı, V.; Doğan, Y.; Talan, T. Effectiveness of online learning: A multi-complementary approach research with responses from the COVID-19 pandemic period. Interact. Learn. Environ. 2021. [CrossRef]

46. Siyam, N.; Abdallah, S. A Pilot Study Investigating the Use of Mobile Technology for Coordinating Educational Plans in Inclusive Settings. J. Spec. Educ. Technol. 2021. [CrossRef]

47. Ngubane-Mokiwa, S.A.; Zongozzi, J.N. Exclusion Reloaded: The Chronicles of Covid-19 on Students with Disabilities in a South African Open Distance Learning Context. J. Intellect. Disabil.-Diagn. Treat. 2021, 9, 137-147. [CrossRef]

48. Sugino, C. Student perceptions of a synchronous online cooperative learning course in a Japanese women's university during the COVID-19 pandemic. Educ. Sci. 2021, 11, 231. [CrossRef]

49. Reddy, P.; Sharma, B.; Chaudhary, K. Digital literacy: A review in the South Pacific. Comput. High Educ. 2021. [CrossRef]

50. Page, A.; Anderson, J.; Charteris, J. Including students with disabilities in innovative learning environments: A model for inclusive practices. Int. J. Incl. Educ. 2021. [CrossRef]

51. Prado, Y.; Jacob, S.; Warschauer, M. Teaching computational thinking to exceptional learners: Lessons from two inclusive classrooms. Comput. Sci. Educ. 2021. [CrossRef]

52. Paiva, D.M.B.; Freire, A.P.; de Mattos Fortes, R.P. Accessibility and Software Engineering Processes: A Systematic Literature Review. J. Syst. Softw. 2021, 171, 1-17. [CrossRef]

53. Uygur, M.; Ayçiçek, B.; Doğrul, H.; Yelken, T.Y. Investigating stakeholders' views on technology integration: The role of educational leadership for sustainable inclusive education. Sustainability 2020, 12, 10354. [CrossRef]

54. Tomczyk, Ł.; Potyrała, K.; Włoch, A.; Wnęk-Gozdek, J.; Demeshkant, N. Evaluation of the functionality of a new e-learning platform vs. Previous experiences in e-learning and the self-assessment of own digital literacy. Sustainability 2020, $12,10219$. [CrossRef]

55. Schuck, R.K.; Lambert, R. “Am I Doing Enough?” Special Educators' Experiences with Emergency Remote Teaching in Spring 2020. Educ. Sci. 2020, 10, 320. [CrossRef]

56. Sá, M.J.; Serpa, S. COVID-19 and the promotion of digital competences in education. Univers. J. Educ. Res. 2020, 8, 4520-4528. [CrossRef]

57. AlTaher, B.B. Inclusive multicultural videos: An engaging approach in teaching higher educational levels of English. Univers. J. Educ. Res. 2020, 8, 4536-4544. [CrossRef]

58. Torres, K.M.; Giddie, L. Educator Perceptions and Use of Technology in South African Schools. Peabody J. Educ. 2020, 95, 117-126. [CrossRef]

59. Sunderland, N.; Woods, G.; Dorsett, P. Making the Invisible Visible: Applying Digital Storytelling for Immersive, Transformative and Anti-Colonial Learning. Br. J. Soc. Work. 2020, 50, 483-505. [CrossRef]

60. Pugach, M.C.; Blanton, L.P.; Mickelson, A.M.; Boveda, M. Curriculum Theory: The Missing Perspective in Teacher Education for Inclusion. Teach. Educ. Spec. Educ. 2020, 43, 85-103. [CrossRef]

61. Kozleski, E.B.; Proffitt, W.A. A Journey Towards Equity and Diversity in the Educator Workforce. Teach. Educ. Spec. Educ. 2020, 43, 63-84. [CrossRef]

62. Moriña, A. Approaches to inclusive pedagogy: A systematic literature review. Pedagogika 2020, 140, 134-154. [CrossRef]

63. Gunawardena, C.N. Culturally inclusive online learning for capacity development projects in international contexts. J. Learn. Dev. 2020, 7, 5-30.

64. Rich, B.L. How are culturally inclusive teaching practices integrated into business school's curriculum? An analysis of syllabi from the United States. Int. J. Incl. Educ. 2020. [CrossRef]

65. Khandelwal, R.; Kolte, A.; Pawar, P.; Martini, E. Breaking out of your comfort zone: An archival research on epistemology in inclusive education pedagogy for Industry 4.0. Int. J. Educ. Manag. 2020. [CrossRef]

66. de Klerk, E.D.; Palmer, J.M. Exploring transformative social justice teaching: A south african education policy perspective. Issues Educ. Res. 2020, 30, 828-844.

67. Fanea-Ivanovici, M.; Pana, M.-C. From Culture to Smart Culture. How Digital Transformations Enhance Citizens' Well-Being through Better Cultural Accessibility and Inclusion. IEEE Access 2020, 8, 37988-38000. [CrossRef] 
68. Karademir Coşkun, T. The effectiveness of robot training in special education: A robot training model proposal for special education. Interactive Learning Environments. Adv. Online Publ. 2020. [CrossRef]

69. Ayalew, A.T.; Adane, D.T.; Obolla, S.S.; Ludago, T.B.; Sona, B.D.; Biewer, G. From Community-Based Rehabilitation (CBR) Services to Inclusive Development. A Study on Practice, Challenges, and Future Prospects of CBR in Gedeo Zone (Southern Ethiopia). Front. Educ. 2020. [CrossRef]

70. Maher, A.J.; Thomson, A.; Parkinson, S.; Hunt, S.; Burrows, A. Learning about 'inclusive' pedagogies through a special school placement. Phys. Educ. Sport Pedagog. 2020. [CrossRef]

71. Draper, A.R.; Bartolome, S.J. Academy of Music and Arts for Special Education (AMASE): An Ethnography of an Individual Music Instruction Program for Students With Disabilities. J. Res. Music. Educ. 2021, 69, 258-283. [CrossRef]

72. Moosa, V.; Shareefa, M.; Adams, D.; Mohamed, A. Assessing Teacher Readiness for Inclusive Education in Maldives: Instrument Modification and Validation. Int. J. Disabil. Dev. Educ. 2020. [CrossRef]

73. Vantieghem, W.; Roose, I.; Gheyssens, E.; Griful-Freixenet, J.; Keppens, K.; Vanderlinde, R.; Struyven, K.; Van Avermaet, P. Professional vision of inclusive classrooms: A validation of teachers' reasoning on differentiated instruction and teacher-student interactions. Stud. Educ. Eval. 2020, 67, 100912. [CrossRef]

74. Kauffman, J.M.; Ahrbeck, B.; Anastasiou, D.; Badar, J.; Felder, M.; Hallenbeck, B.A. Special Education Policy Prospects: Lessons From Social Policies Past. Exceptionality 2021, 29, 16-28. [CrossRef]

75. Bottini, S.; Gillis, J. Use of an Online Training with Virtual Role Play to Teach Preference Assessment Implementation. J. Dev. Phys. Disabil. 2021, 33, 931-945. [CrossRef] [PubMed]

76. Lukovenko, T.; Kalugina, N.; Sorokin, N.; Bulavenko, O. Accompanying Persons with Disabilities at University: Skills Development among Volunteers. Int. J. Instr. 2021, 14, 935-952. [CrossRef]

77. Alghamdi, A.K.H.; Al-Ghamdi, N.A. Elementary teachers' thoughts about distance education and learning 21st-century skills during covid pandemic. Int. J. Learn. Teach. Educ. Res. 2021, 20, 33-50. [CrossRef] 